\title{
Physiological changes in eucalyptus hybrids under different irrigation regimes $^{1}$
}

\author{
Alterações fisiológicas em híbridos de eucalipto sob diferentes regimes de irrigação
}

\author{
Jane Valadares ${ }^{2}$, Nádia Figueiredo de Paula $^{3}$ e Rinaldo Cesar de Paula ${ }^{4 *}$
}

\begin{abstract}
With the expansion of the cultivation of eucalyptus into areas with limited water resources, recommending genotypes which are tolerant to low water availability is important in order to maximize productivity under such conditions. The aim of this work therefore was to evaluate five hybrids of Eucalyptus grandis $\mathrm{x}$ E. urophylla (H1 to $\mathrm{H} 5)$ subjected to four irrigation regimes in the greenhouse: daily (IR1), every two days (IR2), every four days (IR4) and every six days (IR6). The following characteristics were evaluated: photosynthetic rate $(A)$, transpiration $(E)$, stomatal conductance $\left(g_{s}\right)$, leaf water potential $\left(\Psi_{\mathrm{w}}\right)$, leaf relative water content, photochemical efficiency and chlorophyll content index. Evaluations of $A, g_{s}$ and $E$ were carried out on two occasions: 1 - under stress, at the end of the interval between irrigations for each treatment; and 2 - in recovery, $48 \mathrm{~h}$ after irrigation for all plants in the experiment. On average, there was reduction of 25 and $40 \%$ in $A$ values, 40 and 55\% in $g, 15$ and $22 \%$ in $E$, and 96 and $103 \%$ in $\Psi w$ respectively in those plants under regimes IR4 and IR6, compared to under IR1. Stomatal conductance had only partially recovered $48 \mathrm{~h}$ after irrigation, and due to being more sensitive, its changes are a good indication of water stress. Hybrid $\mathrm{H} 3$ is the most tolerant and $\mathrm{H} 5$ the most sensitive to a reduction in water availability in soil.
\end{abstract}

Key words: Water stress. Forest improvement. Physiological characteristics.

RESUMO - Com a expansão da cultura do eucalipto para áreas com grandes limitações hídricas, torna-se importante a recomendação de genótipos tolerantes à baixa disponibilidade hídrica para a maximização da produtividade nestas condições. Assim, este trabalho objetivou avaliar cinco híbridos de Eucalyptus grandis x E. urophylla (H1 a H5) submetidos a quatro regimes de irrigação, em casa de vegetação: irrigação diária (RI1) e a cada dois (RI2), quatro (RI4) e seis dias (RI6). Avaliou-se a taxa fotossintética $(A)$, transpiração $(E)$, condutância estomática $\left(g_{s}\right)$, potencial hídrico $\left(\Psi_{w}\right)$ e conteúdo relativo de água nas folhas, eficiência fotoquímica e índice de conteúdo de clorofila. As avaliações de $A, g_{s}$ e $E$ foram realizadas em dois momentos: 1 - sob estresse: ao final do intervalo entre as irrigações de cada regime hídrico e 2 - sob recuperação: 48 h após a irrigação de todas as plantas do experimento. Em média, houve redução de 25 e $40 \%$ nos valores de $A$, de 40 e $55 \%$ em $g_{s}$, de 15 e $22 \%$ em $E$ e de 96 e $103 \%$ no $\Psi_{w}$ respectivamente, nas plantas submetidas aos regimes RI4 e RI6, comparativamente ao RI1. A condutância estomática recuperou-se apenas parcialmente, 48 h após a irrigação e, por apresentar-se mais sensível, suas alterações são boas sinalizadoras do estresse hídrico. O híbrido H3 é o mais tolerante e o H5 o mais sensível à redução da disponibilidade hídrica no solo.

Palavras-chave: Estresse hídrico. Melhoramento florestal. Características fisiológicas.

\footnotetext{
*Autor para correspondência

${ }^{1}$ Recebido para publicação em 20/09/2013; aprovado em 26/06/2014

Parte da Tese de Doutorado da primeira autora apresentada ao Programa de Pós-Graduação em Agronomia/Genética e Melhoramento de Plantas, Faculdade de Ciências Agrárias e Veterinárias/FCAV, Universidade Estadual Paulista/UNESP, Campus de Jaboticabal

${ }^{2}$ Programa de Pós-Graduação em Agronomia/Genética e Melhoramento de Plantas, Faculdade de Ciências Agrárias e Veterinárias/FCAV, Universidade Estadual Paulista/UNESP, Campus de Jaboticabal, Jaboticabal-SP, Brasil, 14.884-900, jane_valadares@yahoo.com.br ${ }^{3}$ Faculdade de Tecnologia de Jaboticabal/FATEC-JB, Jaboticabal-SP, Brasil, 14.884-900, nadfigueiredo@ gmail.com

${ }^{4}$ Departamento de Produção Vegetal, Faculdade de Ciências Agrárias e Veterinárias/FCAV, Universidade Estadual Paulista/UNESP, Campus de Jaboticabal, Jaboticabal-SP, Brasil, Bolsista PQ-CNPq, rcpaula@fcav.unesp.br
} 


\section{INTRODUCTION}

Plants are often subject to factors that impair their growth, such as unfavourable conditions of solar radiation, water availability and temperature. Of these, the low availability of water (both in the atmosphere and in the soil) is identified as one of the factors which most limits productivity in planted forests of Eucalyptus (CORREIA et al., 2014; PEPPER et al., 2008; STAPE et al., 2010; VILLAR et al., 2011).

Reduced water availability triggers a series of physiological, biochemical and molecular responses in plants (LAWLOR, 2009; PINHEIRO; CHAVES, 2011). As soon as the roots detect a decrease in soil moisture, water potential and cell turgor are reduced. The roots produce abscisic acid (ABA) which is carried to the leaves where, in addition to mediating hydraulic changes, it promotes stomatal closure, in this way limiting gas exchange and leaf growth (BEDON et al., 2011; PINHEIRO; CHAVES, 2011).

The physiological and biochemical changes most commonly observed as the responses of plants to drought include closure of the stomata (with a consequent reduction in stomatal conductance, the rate of photosynthesis and transpiration), reduced water potential and water content of the leaves, an increase in the synthesis of osmoprotectors (proline and sugars), protein degradation (FANAEI et al., 2009) and a reduction in the photochemical efficiency of photosystem II, given by the ratio between the variable and maximal fluorescence - Fv/ Fm (BJÖRKMAN; DEMMING, 1987; LIMA, JARVIS, RHIZOPOULOU, 2003; MOSETI; DINTWE, 2011).

Among the morphological changes, the plants display a reduction in leaf area, greater growth of the root system, senescence and leaf drop. However, these changes occur in the long term (CHAVES; MAROCO; PEREIRA, 2003) and in the case of prolonged stress (PINHEIRO; CHAVES, 2011).

Currently, the cultivation of eucalypt is expanding into regions of Brazil having little tradition in forestry and great limitations to crop growth mainly due to low water availability and high temperatures. Tree improvement programs carried out in Brazil were primarily aimed at growth characteristics, and more recently the wood quality. Indirectly, selection has been based on adaptation to the environmental conditions in which the companies operated, and it may be assumed that tolerance to drought was not a characteristic fully addressed in these programs (PAULA, PAULA; MARINO, 2012). Forestry companies therefore do not always possess genotypes which are recommended for the new frontiers of Eucalyptus planting, so that the study of the behaviour of genotypes developed for other conditions of soil and climate becomes of great interest to the forestry sector. Accordingly, the present study aimed to evaluate possible changes in the physiological characteristics of the seedlings of five hybrids of Eucalyptus grandis $\mathrm{x}$ E. urophylla under different irrigation regimes in greenhouse, with the objective of aiding breeding programs for drought tolerance in the Eucalyptus.

\section{MATERIAL AND METHODS}

The study was carried out in a greenhouse located at the School of Agrarian Sciences and Veterinary Medicine, at Jaboticabal Campus of the São Paulo State University, in Jaboticabal, São Paulo, Brazil. According to Köppen classification, the climate in the area is of type Cwa, with an annual average precipitation of $1,425 \mathrm{~mm}$, temperature of $22.2^{\circ} \mathrm{C}$ and relative humidity of $75 \%$ (ANDRIOLI; CENTURION, 1999). Black plastic pots were used, filled with $10.5 \mathrm{~kg}$ of a Quartz Arenite Neosol (Table 1) which, after drying and sieving, was fertilized following the recommendations of Gonçalves, Van Raij and Gonçalves (1997). During the experimental period, the maximum temperature inside the greenhouse ranged from 22 to $38^{\circ} \mathrm{C}$, with the minimum between 14 and 21 ${ }^{\circ} \mathrm{C}$; the maximum relative humidity was 86 to $98 \%$ and the minimum 22 and $85 \%$.

The experimental design was of randomised blocks in a 5 x 4 factorial scheme (5 hybrids of Eucalyptus grandis $\mathrm{x}$ E. urophylla and 4 irrigation regimes), giving a total of 20 treatments with four replications.

Seedlings of the five eucalypt hybrids ( $\mathrm{H} 1, \mathrm{H} 2, \mathrm{H} 3$, $\mathrm{H} 4$ and $\mathrm{H} 5$ ) were produced by the minicutting process, and

Table 1 - Chemical and particle-size analysis of a sample from soil (Quartz Arenite Neosol) used in the experiment

\begin{tabular}{|c|c|c|c|c|c|c|c|c|c|c|c|c|c|c|}
\hline \multicolumn{10}{|c|}{ Chemical Analysis ${ }^{1}$} & \multirow{2}{*}{\multicolumn{5}{|c|}{ Particle-size Analysis ${ }^{4}$}} \\
\hline \multirow{2}{*}{$\mathrm{pH}$} & \multirow{2}{*}{ M.O. } & \multirow{2}{*}{$\mathrm{P}$} & $\mathrm{K}$ & $\mathrm{Ca}$ & $\mathrm{Mg}$ & $\mathrm{H}+\mathrm{Al}$ & SB & $\mathrm{T}$ & $\mathrm{V}$ & & & & & \\
\hline & & & \multicolumn{6}{|c|}{$\mathrm{mmol} \mathrm{dm}^{-3}$} & $\%$ & Cly & $\mathrm{Sm}$ & FS & $\mathrm{CS}$ & $\mathrm{TC}$ \\
\hline 4.9 & 3.5 & 18 & 0.8 & 13 & 4 & 19 & 18.3 & 37.3 & 49 & 57 & 23 & 433 & 487 & $\mathrm{Sa}$ \\
\hline
\end{tabular}

1. Chemical analysis: $\mathrm{pH}$ in $\mathrm{CaCl}_{2}$; M.O. - organic material in $\mathrm{g} \mathrm{dm}^{-3}$; P - Resin Extractor, em mg dm ${ }^{-3}$; SB: Sum of Bases; CE: Cation Exchange Capacity; V: Base Saturation. ${ }^{4}$; Particle-size analysis $\left(\mathrm{g} \mathrm{kg}^{-1}\right)$ : Cly - Clay; Sm - Slime; FS - Fine sand; CS - Course sand; Sa - Sandy; TC - Textural Class 
transplanted into pots at the age of 80 days. At this time, the total weight of the pot, soil, plant and water was determined, where enough water was supplied so as to reach $60 \%$ of the maximum capacity for water retention of the soil (MCWR), also known as "pot capacity", determined according to Fretz, Read and Peele (1979), and corresponding to the maximum volume of water retained by a sample of known mass of dry soil after saturation with a known of volume water and quantification of the volume drained. For 17 days, in order for the seedlings to acclimatise, the pots were watered daily to maintain $60 \%$ of soil MCWR. For a further 66 days after this period of acclimatisation, the seedlings were subjected to four irrigation regimes: daily irrigation (IR1) and at intervals of two (IR2), four (IR4) and six days (IR6). During this time, the amount of water restored to each pot was determined using the gravimetric method, by obtaining the total weight of the pot, plant and soil at intervals corresponding to the irrigation regimes, and replenishing enough to again reach $60 \%$ of the maximum capacity for water retention.

The following characteristics were evaluated in the plants from the different treatments: photosynthetic rate $(A)$, stomatal conductance $\left(g_{s}\right)$ and transpiration $(E)$, using a portable infrared gas analyser (IRGA, LCPro + ) under the ambient $\mathrm{CO}_{2}$ concentration $\left(370 \pm 10 \mu \mathrm{mol} \mathrm{m} \mathrm{m}^{-2} \mathrm{~s}^{-1}\right)$, a photosynthetic photon flux density (PPFD) of 1,000 $\mu \mathrm{mol}$ $\mathrm{m}^{-2} \mathrm{~s}^{-1}$ and a leaf temperature kept at $25{ }^{\circ} \mathrm{C}$; chlorophyll content index (CCI), determined with a chlorophyll meter (Opti-Sciences, Model CCM-200); photochemical efficiency (Fv/Fm), using a chlorophyll fluorometer (Opti-Sciences, Model OS-30p); leaf water potential $\left(\Psi_{w}\right)$ with a pressure pump (model 3005, Santa Barbara Soilmoisture, USA), as per Scholander et al. (1965); and the leaf relative water content (RWC).

Measurements of $A, g_{s}, E$, ICC and Fv/Fm were carried out between 07:30 and 11:30, on a fully expanded leaf taken from the top third of the plant. The evaluations of $A, g_{s}$ and $E$ were done in two stages: when the plants were subjected to the lowest availability of water, i.e. at the end of the period under each water regime of no irrigation (called 'under stress' or 'before irrigation'); and 48 hours after irrigation of all the plants in the experiment (called 'after irrigation' or 'in recovery'). From evaluations of the previous two conditions, the percentage change in the values of $A, g_{s}$ and $E$, both those evaluated $48 \mathrm{~h}$ after irrigation and those obtained under stress, were calculated for each hybrid and irrigation regime. Additionally the variation of these characteristics were calculated for the irrigation regimes IR2, IR4 and IR6 in relation to the regime IR1 which was taken as the reference or control, both under stress or in recovery.

In total, seven evaluations of $A, g_{s}, E, \mathrm{CCI}$ and Fv/Fm were made - at 12, 24, 36, 48, 54, 60 and 66 days after application of the irrigation regimes; three evaluations of relative water content (RWC) - at 54, 60 and 66 days; and two evaluations of leaf water potential $\left(\Psi_{\mathrm{W}}\right)$ - at 54 and 66 days. The evaluations of RWC and $\Psi_{\mathrm{W}}$ were done between 07:00 and 08:30, taking one leaf per plant for each treatment. Fewer evaluations were made for these two features due to the destructive method, which required that leaves be removed. The reason for measuring the $\Psi_{\mathrm{W}}$ at that time was to assess the water status of the plants only and not the water potential of the soil.

The data for the characteristics evaluated, obtained from the average of all the evaluations, underwent variance analysis and F-test separately for the two conditions 'under stress' and 'after irrigation' (or 'in recovery'). The averages for the treatments were compared by Tukey test at $5 \%$ probability.

\section{RESULTS AND DISCUSSION}

There were differences between the hybrids and between the irrigation regimes for most of the characteristics under evaluation, but interaction between these factors was significant only for the relative water content of the leaves, RWC, and for the chlorophyll content index, CCI (Table 2). Under water stress, hybrid $\mathrm{H} 3$ displayed a rate of photosynthesis $(A)$ higher than hybrids $\mathrm{H} 2$ and $\mathrm{H} 5$; in turn, H5 had lower values than the other hybrids. Values of $A$ were also higher in plants subjected to the daily (IR1) and two-day (IR2) irrigation regimes, decreasing with the increase in irrigation interval (Figures 1A and 1D).

After irrigation, i.e. in recovery, differences in the values for $A$ for the hybrids were lower, although for $\mathrm{H} 4$ it was higher than for hybrids $\mathrm{H} 1, \mathrm{H} 2$ and $\mathrm{H} 5$. Plants subjected to irrigation regime IR1 showed lower values for $A$ than plants of IR2, with no differences between plants seen under the other irrigation regimes (Figures 1A and 1D).

Hybrid H5 showed greater sensitivity to the low water availability, with a lower value for photosynthesis under stress (Figure 1A), but with a greater capacity for recovery (Figure 2A). After irrigation, the rates of recovery of photosynthesis were similar for hybrids $\mathrm{H} 2$ and $\mathrm{H} 4$; on the other hand, $\mathrm{H} 1$ and $\mathrm{H} 3$ showed the smallest changes in relation to this condition under stress (Figure 2A). H1 and H3 were therefore more tolerant of the lower water availability, demonstrating the ability to overcome temporary water stress by least altering their rate of photosynthesis and displaying a fast recovery. At least compared to other species of Eucalyptus studied by Ngugi et al. (2004), in which recovery of gas exchange in E. argophloia and E. cloeziana only occurred after 10 days of irrigation. Hybrids of $E$. nitens recovered in four days 
Table 2 - Values of ' $\mathrm{F}$ ', means and coefficients of variation $(\mathrm{CV}, \%)$ for photosynthetic rate $\left(A, \mu \mathrm{mol} \mathrm{m}^{-2} \mathrm{~s}^{-1}\right)$, stomatal conductance $\left(g_{s}, \mathrm{~mol} \mathrm{~m}^{-2} \mathrm{~s}^{-1}\right)$, transpiration $\left(E \mathrm{mmol} \mathrm{m} \mathrm{m}^{-2} \mathrm{~s}^{-1}\right)$, leaf water potential ( $\left.\Psi \mathrm{w}, \mathrm{MPa}\right)$, photochemical efficiency $(\mathrm{Fv} / \mathrm{Fm})$, relative water content of the leaves (RWC, \%) and chlorophyll content index (CCI) in plants of five hybrids of E. grandis x E. urophylla, subjected to a daily irrigation regime (IR1) and every two (IR2), four (IR4) and six days (IR6), before (under stress) and $48 \mathrm{~h}$ after irrigation

\begin{tabular}{|c|c|c|c|c|c|c|c|c|c|c|}
\hline \multirow{3}{*}{ Source of Variation } & \multicolumn{10}{|c|}{ 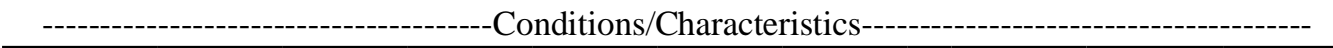 } \\
\hline & \multicolumn{7}{|c|}{ Before irrigation (under stress) } & \multicolumn{3}{|c|}{ After irrigation } \\
\hline & $A$ & $g s$ & $E$ & $\Psi_{\mathrm{W}}$ & $\mathrm{Fv} / \mathrm{Fm}$ & RWC & $\mathrm{CCI}$ & $A$ & $g s$ & $E$ \\
\hline Hybrids & $11.6^{* *}$ & $2.6^{*}$ & $1.9^{\mathrm{ns}}$ & $7.8 * *$ & $4.7 * *$ & $8.8 * *$ & $24.6 * *$ & $5.4 * *$ & $2.3^{\mathrm{ns}}$ & $2.9 *$ \\
\hline IR & $132.8 * *$ & $63.7 * *$ & $46.4 * *$ & $37.7 * *$ & $0.1^{\text {ns }}$ & $26.9 * *$ & $26.7 * *$ & $4.8 * *$ & $9.6 * *$ & $1.2^{\mathrm{ns}}$ \\
\hline Hyb x IR & $1.2^{\mathrm{ns}}$ & $0.8^{\mathrm{ns}}$ & $0.9^{\mathrm{ns}}$ & $1.3^{\mathrm{ns}}$ & $1.2^{\mathrm{ns}}$ & $2.5 * *$ & $2.5^{* *}$ & $1.8^{\mathrm{ns}}$ & $0.9^{\text {ns }}$ & $1.3^{\mathrm{ns}}$ \\
\hline Mean & 11.15 & 0.320 & 2.05 & -0.83 & 0.819 & 90.83 & 13.29 & 12.8 & 0.377 & 2.32 \\
\hline $\mathrm{CV}(\%)$ & 8.74 & 19.34 & 7.33 & 27.66 & 1.37 & 2.49 & 11.03 & 7.29 & 14.79 & 4.67 \\
\hline
\end{tabular}

IR - Irrigation regimes; Hyb - Hybrids. ${ }^{\text {ns }}$-not significant by F-test $(p>0.05) ; *$ and $* *$ significant by F-test $(p \leq 0.05 ; p \leq 0.01)$ respectively

(MOKOTEDI, 2010) and a clone of E. grandis x $E$. urophylla after seven days (EKSTEEN et al., 2013) of irrigation. In forest species in Tasmania, recovery occurred within $24 \mathrm{~h}$ in moderately stressed plants and up to 20 days in severely stressed plants which even came to have damage to their leaves (BLACKMAN; BRODRIBB; JORDAN, 2009). For these authors, the recovery rate for gas exchange depends on the severity of the stress imposed, and is strongly correlated with the recovery of hydraulic conductivity.

The reduction in the photosynthetic rate under the less frequent irrigation regimes (IR4 and IR6) was due to stomatal closure, also evidenced by the low values for stomatal conductance $\left(g_{s}\right)$ under these regimes (Figures 1B and 1D). Hu, Chen and $\mathrm{Hu}$ (2012) observed in $E$. grandis that from the sixth day without irrigation, $A$ and $g_{s}$ decreased dramatically to almost zero by the ninth day. Water stress, besides limiting $\mathrm{CO}_{2}$ assimilation through stomatal closure, affects metabolism in the mesophyll, reducing photosynthetic capacity (CHAVES; MAROCO; PEREIRA, 2003; LAWLOR, 2009; PINHEIRO; CHAVES, 2011). There was a high rate of recovery for photosynthesis in plants under IR4 and IR6, and little change under IR1 and IR2 (Figure 2B). Indeed, the IR1 and IR2 regimes were not sufficient to promote water stress in the five hybrids. Also, 48 hours after irrigation, a recovery was seen in the rate of photosynthesis in the five hybrids (Figure 1A). Similar values for photosynthesis were observed in plants from 18 clones of Eucalyptus spp under daily irrigation and every two days, comparable to the recovery of this characteristic under the less frequent irrigation regimes (four and six days) after $24 \mathrm{~h}$ of irrigation (VELLINI et al., 2008). For Warren, Aranda and Cano (2011), the recovery rate for photosynthesis depends on the genotype and the degree of dehydration reached during stress. Whereas Chaves, Flexas and Pinheiro (2009) state that, in general, the photosynthetic rate recovers in one or two days after irrigation, which agrees with the results obtained in the present research.

Compared to regime IR1, the photosynthetic rate under stress did not change in plants subjected to IR2, but was reduced in about $25 \%$ of the plants under IR 4 and $40 \%$ under RI6 (Figure 3). This demonstrates that daily irrigation (IR1) so as to maintain $60 \%$ of the water retaining capacity of the substrate, did not result in any physiological benefit to the plants of the five eucalypt hybrids, compared to those irrigated every two days (IR2).

Before irrigation, hybrid $\mathrm{H} 3$ displayed a greater value for $g_{s}$ than $\mathrm{H} 5$, with no differences for the other hybrids, however after irrigation they displayed similar behaviour (Figure 1E). After irrigation, there was partial recovery of the values for $g_{s}$ (Figures 1B and 3) with lower values in the plants subjected to regimes IR4 and IR6, albeit with an increase of $38 \%$ in the plants under IR4 and 69\% under IR6, against only $6 \%$ in the plants under IR2 (Figure 2B). These results show that the period of 48 hours after irrigation was not sufficient for the full recovery of stomatal conductance $\left(g_{s}\right)$ in plants under the less frequent irrigation regimes (IR4 and IR6), probably requiring further irrigation. Chaves, Flexas and Pinheiro (2009), referring to several authors, state that in plants subjected to mild to moderate water stress, recovery after irrigation is rapid, usually within one to two days, but in plants subject to severe water stress, recovery is continuous and not always complete. Blackman, Brodribb and Jordan (2009) noted that recovery of stomatal conductance occurred within $24 \mathrm{~h}$ in four temperate woody species. Similarly, Vellini et al. (2008) found that after $24 \mathrm{~h}$ of irrigation, recovery was seen in plants from 18 eucalyptus clones subjected to different irrigation regimes.

Stomatal conductance was more sensitive to withholding irrigation, displaying a proportionally 
Figure 1 - Photosynthetic rate ( $A$ and D), stomatal conductance (B and E), and transpiration (C and F) before irrigation (under stress) and after irrigation, in plants of five hybrids of E. grandis x E. urophylla (on the right) under a daily irrigation regime (on the left) (IR1) and every two (IR2), four (IR4) and six days (IR6)
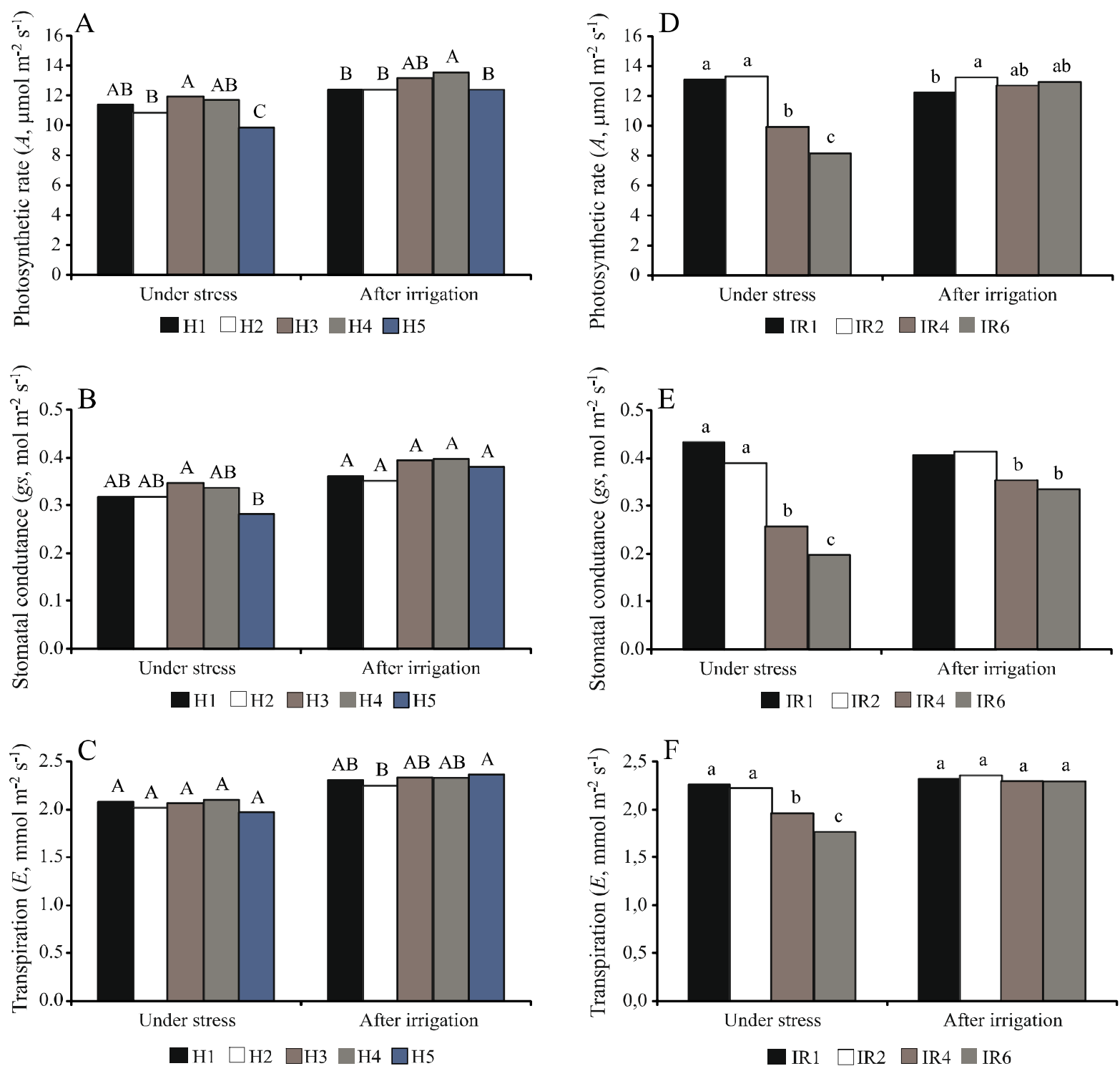

Averages followed by the same letter, upper case for hybrid and lower case for irrigation regime, do not differ by Tukey test ( $p>0.05$ )

greater reduction under stress (Figure 3) compared to the rates of photosynthesis and transpiration. It was also seen that the experimental coefficient of variation for $g_{s}$ (Table 2), close to $20 \%$ under stress and $15 \%$ in recovery, were approximately twice those obtained for the photosynthetic rate $(A)$ and about three times the rate of transpiration $(E)$, displaying greater heterogeneity in the results obtained for stomatal conductance, which may be due to the greater destabilisation of stomatal function. According to Angelocci et al. (2004), stomatal responses to environmental conditions are extremely complex, and variations in temperature, light, relative humidity and wind speed affect stomatal control.

Hybrid H5 showed greater recovery of $g_{s}$ after irrigation, for the average water regime, with an increase of around $35 \%$ in stomatal conductance; on the other hand, $\mathrm{H} 2$ had the lowest recovery rate of $10 \%$ (Figure $2 \mathrm{~A}$ ). There was a reduction in the values of $g_{s}$ under stress, of approximately 10, 40 and $55 \%$ respectively in plants under irrigation regimes IR2, IR4 and IR6; and after 48 $\mathrm{h}$ of irrigation, recovery for this characteristic was total 
under regime IR2, and $87 \%$ and $82 \%$ under IR4 and IR6, in relation to IR1 (Figure 3). So in the same way that stomatal closure is one of the earliest plant responses to water stress, reducing the values for $g_{s}$ as a consequence, the results show that this characteristic demands more time for a full recovery after a period of water stress, confirming the information of Chaves, Flexas and Pinheiro (2009) mentioned above.

Stomatal closure leads to a reduction in carbon assimilation by the leaves, on the other hand it reduces the loss of water, avoiding or minimising damage through dehydration of the cells and tissues (PITA et al., 2005). According to Chaves, Flexas and Pinheiro (2009) stomatal responses are more related to the water content of the soil than to the water status of the leaf, showing that the stomata respond to chemical signals (e.g. abscisic acid - ABA) produced by dehydration of the root during water stress, whereas the water status of the leaf remains constant. However, according to Pita et al. (2005), there is a lack of clear understanding of how the signs of water stress, noticed in the root, are integrated to control

Figure 2 - Variation $(\%)$ in photosynthetic rate $(A)$, stomatal conductance $\left(\mathrm{g}_{\mathrm{s}}\right)$ and transpiration $(E)$, after irrigation in plants of five hybrids of E. grandis x E. urophylla under a daily irrigation regime (IR1) and every two (IR2), four (IR4) and six days (IR6). A) between hybrids (H1 to H5); B) between irrigation regimes (IR1, IR2, IR4 and IR6)

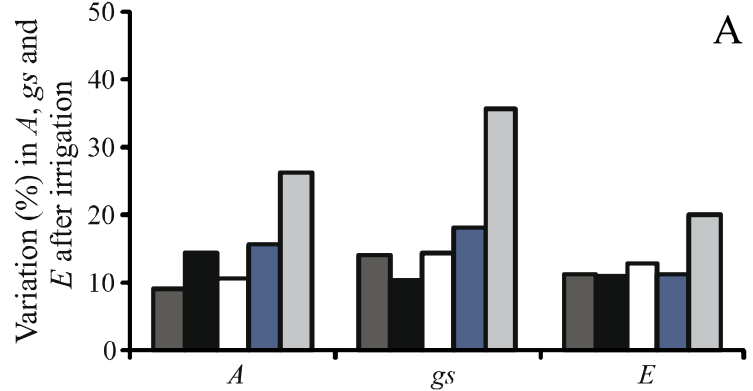

$\square \mathrm{H} 1 \square_{\mathrm{H} 2} \square \mathrm{H} 3 \square \mathrm{H} 4 \square \mathrm{H} 5$

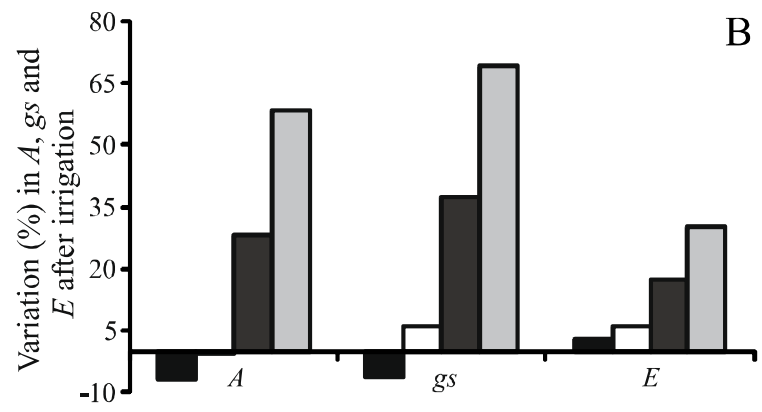

IR1 $\square$ IR2 $\square$ IR4 $\square$ IR6

Figure 3 - Variation $(\%)$ in the photosynthetic rate $(A)$, stomatal conductance $\left(g_{s}\right)$ and transpiration $(E)$ in plants of five hybrids of $E$. grandis $\mathrm{x}$ E. urophylla under irrigation regimes every 2 (IR2), four (IR4) and six days (IR6), in relation to the daily irrigation regime (IR1), before (under stress) and after irrigation

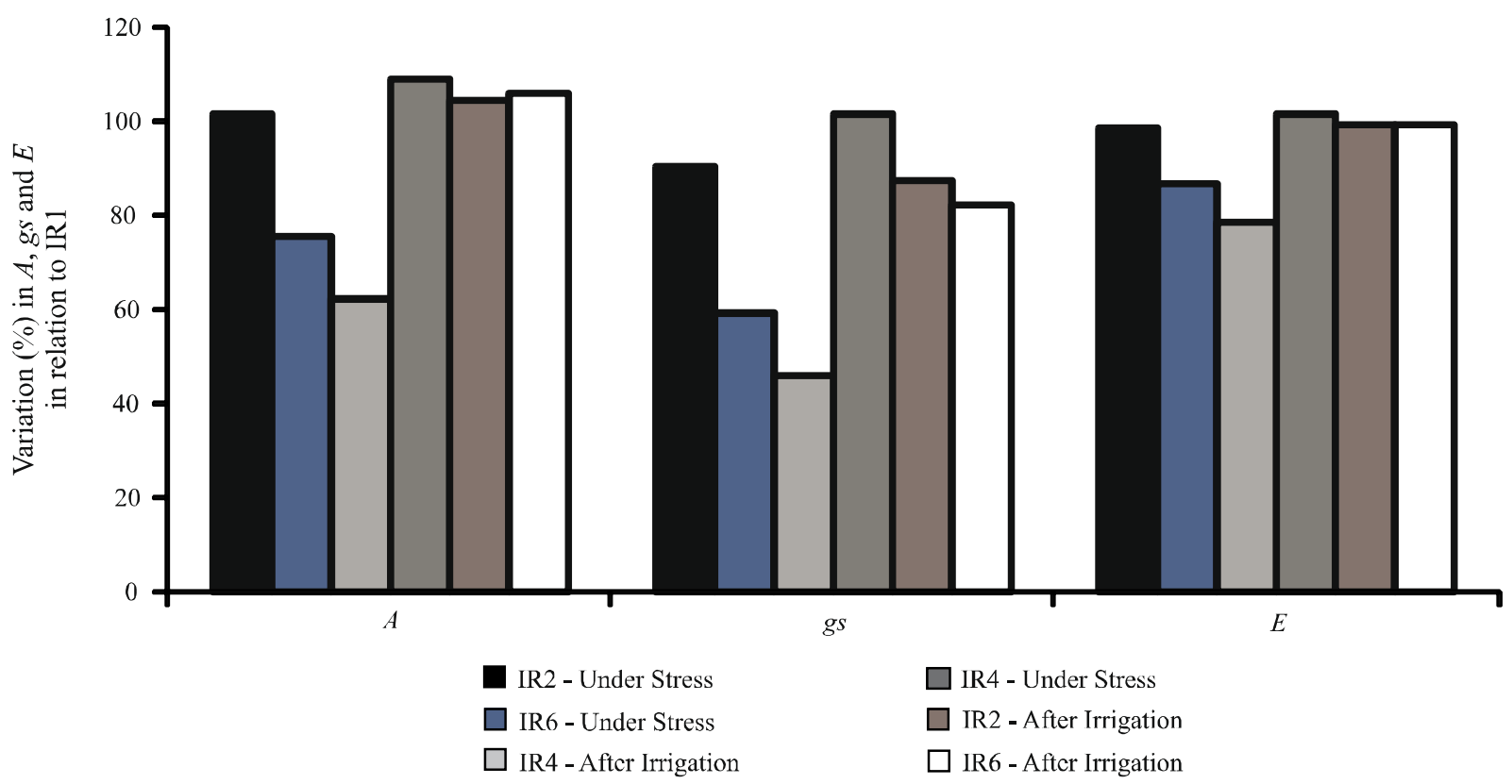


stomatal conductance, and how they act in plants with different strategies for drought tolerance. Although the water content of the soil has not been quantified here, plants under the less frequent irrigation regimes (IR4 and IR6) had less water available to them, which resulted not only in a reduction in the values of $A, g_{s}$ and $E$, but also in the water potential $(\Psi \mathrm{w})$ and the relative water content (RWC) of the leaves (Figure 4, Table 3).

Stomatal conductance is the reference by which to evaluate the degree of water stress in plants, due to its good sensitivity to changes in water availability (EKSTEEN et al., 2013). As it provides a connection between the loss of water through transpiration and the increase in $\mathrm{CO}_{2}$ (and hence in growth), and between the water saved through stomatal closure and increased heat stress, Pita et al. (2005) considered $g_{s}$ to be a useful tool in genetic improvement for greater productivity in environments subject to drought. Changes in $g_{s}$ are therefore of great importance, because genotypes that exhibit good stomatal control when subjected to water shortages can tolerate or withstand longer periods of water deficiency in the soil.

At the end of the period with no irrigation, the rate of transpiration $(E)$ was different for the plants under the irrigation regimes, but not for the hybrids

Figure 4 - Leaf water potential ( $\left.\Psi_{\mathrm{w}}, \mathrm{MPa}\right)$ and photochemical efficiency $(\mathrm{Fv} / \mathrm{Fm})$ in plants of five hybrids of $E$. grandis $\mathrm{x}$ E. urophylla (A) under irrigation regimes (B) daily (IR1), and every two (IR2), four (IR4) and six days (IR6)
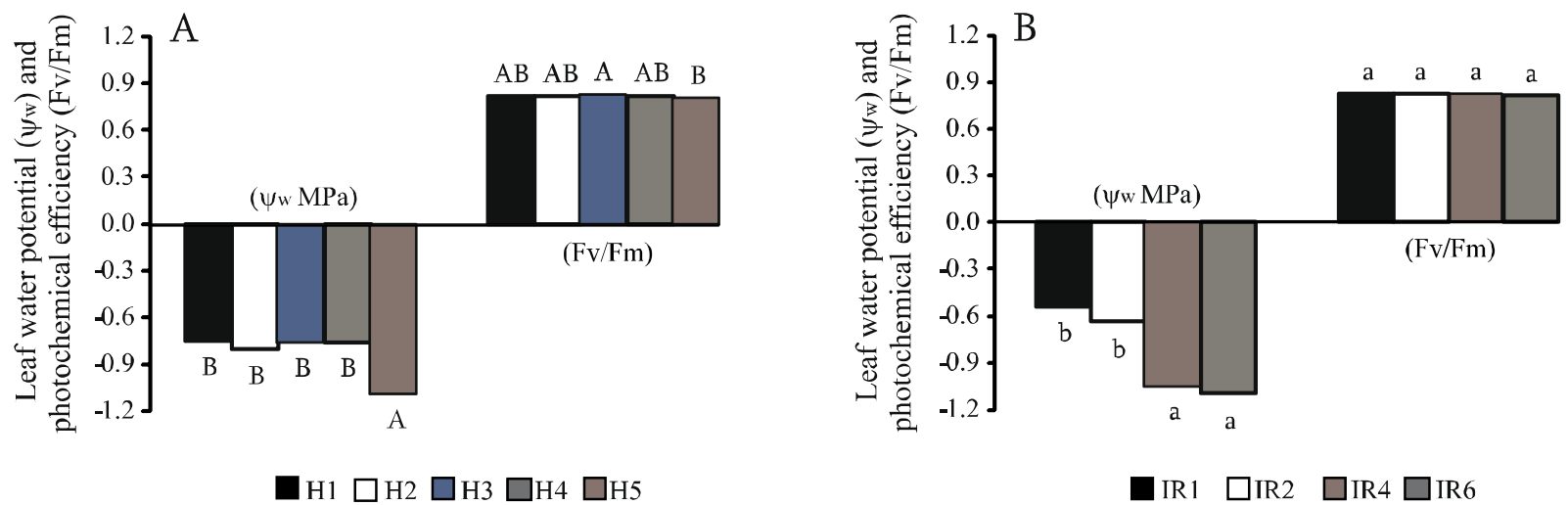

Averages followed by the same letter, upper case for hybrid and lower case for irrigation regime, do not differ by Tukey test $(p>0.05)$

Table 3 - Relative water content (RWC) and chlorophyll content index (CCI) in plants of five hybrids of E. grandis x E. urophylla under a daily irrigation regime (IR1) and every two (IR2), four (IR4) and six days (IR6)

\begin{tabular}{ccccc}
\hline \multirow{2}{*}{ Hybrid/Irrigation regime } & \multicolumn{5}{c}{ RWC } \\
\cline { 2 - 5 } & IR1 & IR2 & IR4 & IR6 \\
\hline $\mathrm{H} 1$ & $92.6 \mathrm{Aa}$ & $92.9 \mathrm{Aa}$ & $91.8 \mathrm{Aa}$ & $89.9 \mathrm{Aa}$ \\
$\mathrm{H} 2$ & $92.9 \mathrm{Aa}$ & $93.2 \mathrm{Aa}$ & $91.1 \mathrm{Aa}$ & $90.0 \mathrm{Aa}$ \\
$\mathrm{H} 3$ & $93.5 \mathrm{Aa}$ & $92.7 \mathrm{Aa}$ & $89.9 \mathrm{Aab}$ & $88.5 \mathrm{Ab}$ \\
$\mathrm{H} 4$ & $92.5 \mathrm{Aab}$ & $93.1 \mathrm{Aa}$ & $90.1 \mathrm{Aab}$ & $88.9 \mathrm{Ab}$ \\
$\mathrm{H} 5$ & $93.3 \mathrm{Aa}$ & $91.6 \mathrm{Aa}$ & $83.5 \mathrm{Bb}$ & $84.5 \mathrm{Bb}$ \\
\hline & & $\mathrm{CCI}$ & \\
\hline $\mathrm{H} 1$ & $10.76 \mathrm{Ba}$ & $12.26 \mathrm{ABa}$ & $11.48 \mathrm{Ba}$ & $12.62 \mathrm{Ca}$ \\
$\mathrm{H} 2$ & $12.34 \mathrm{ABb}$ & $13.40 \mathrm{Aab}$ & $14.92 \mathrm{Aa}$ & $14.32 \mathrm{Cab}$ \\
$\mathrm{H} 3$ & $11.96 \mathrm{ABb}$ & $12.06 \mathrm{ABb}$ & $12.10 \mathrm{Bb}$ & $14.96 \mathrm{BCa}$ \\
$\mathrm{H} 5$ & $13.96 \mathrm{Ac}$ & $14.52 \mathrm{Abc}$ & $16.44 \mathrm{Aab}$ & $18.68 \mathrm{Aa}$ \\
\hline
\end{tabular}

Averages followed by the same letter, upper case in a column and lower case for irrigation regime, do not differ by Tukey test $(p>0.05)$ 
(Figures 1C and 1F). The least frequent irrigation regime (IR6) gave the lowest value for $E$, followed by IR4. In the absence of an adequate supply of water, the loss of turgidity stimulates the closure of the stomata, reducing transpiration. After irrigation, there were differences between the hybrids, but not between the irrigation regimes (Figures $1 \mathrm{C}$ and $1 \mathrm{~F}$ ). In recovery, hybrid $\mathrm{H} 5$ showed greater transpiration than $\mathrm{H} 2$, with no significant differences for the other hybrids. There were also no differences between plants under the various irrigation regimes, demonstrating the good recovery of this characteristic, even in those plants under regime IR6 (Figures 1F, 2 and 3). Differences in transpiration were seen between two clones of $E$. globulus at the time of maximum stress, however one day after irrigation, transpiration had increased in both clones, and a week later there was a full recovery, matching that of those plants which were irrigated daily (CORREIA et al., 2014).

Leaf water potential $\left(\Psi_{w}\right)$ was lower in hybrid H5 compared to the other hybrids; for the irrigation regimes, there were no differences between plants under IR1 and IR2 that in turn displayed higher values than plants under IR4 or IR6 (Figures 4A and 4B). The lowest $\Psi_{w}$, together with the lowest rate of transpiration $(E)$ displayed by $\mathrm{H} 5$ under IR6, indicate that the lower availability of water in the soil, caused by the longer interval between irrigations, limited opening of the stomata.

The water content of the leaves (RWC) was greater than $90 \%$ in plants under irrigation regimes IR1 and IR2, not differing for the hybrids (Table 3). Under regimes IR4 and IR6, $\mathrm{H} 5$ displayed an RWC of 83.5 and $84.5 \%$ respectively, these values being lower than those observed for the other hybrids. $\mathrm{H} 1$ and $\mathrm{H} 2$ showed small changes in RWC under the four irrigation regimes; $\mathrm{H} 3$ and $\mathrm{H} 4$ had a significant reduction in RWC under IR6 only, and H5 showed a significant reduction in RWC under IR4 and IR6. H5 also showed the lowest values for $A$ and $g s$, thereby displaying a greater sensitivity to water stress. In plants under water stress, changes in stomatal conductance take place rapidly, within minutes, in order to regulate water loss in relation to absorption, with the RWC therefore decreasing very little (LAWLOR; TEZARA, 2009). These authors state that a $50 \%$ reduction in stomatal conductance is related to a reduction of approximately $10 \%$ in RWC and $0.5 \mathrm{MPa}$ in water potential and, according to Smit and Singels (2006), RWC values below $75 \%$ being able to limit physiological activities. The greatest reductions in RWC occurred in H5 plants under the IR6 and IR4 irrigation regimes, which if compared to the values observed for plants under IR1, give a reduction of 10 percentage points (Table 3). For the five hybrids, the average reduction in stomatal conductance under stress was approximately $55 \%$ (Figures 1B, 1D, 2 and 3) with $0.56 \mathrm{MPa}$ in water potential, if comparing the values obtained for plants under IR1 and IR6. These values are therefore consistent with the assertions of Lawlor and Tezara (2009). Chaves et al. (1992) observed that in Lupinus albus under optimal or suboptimal temperatures for photosynthesis $\left(25\right.$ and $15^{\circ} \mathrm{C}$ respectively), photosynthetic capacity decreased only when the RWC was close to $60 \%$, but at temperatures above the optimal $\left(35^{\circ} \mathrm{C}\right)$ photosynthetic capacity was affected, with a RWC of around $80 \%$.

For photochemical efficiency $(\mathrm{Fv} / \mathrm{Fm})$, the only difference was between the hybrids $\mathrm{H} 3$ and $\mathrm{H} 5$, however with values within the range considered as normal, between 0.75 to 0.85 (CORREIA et al., 2014). The failure to detect differences in photochemical efficiency between plants under different irrigation regimes (Figure 4B) shows that the reactions of photosystem II were not affected by the water treatments. This suggests that photoinhibition, often considered one of the effects of water stress (BJÖRKMAN; DEMMING, 1987; MOSETI; DINTWE, 2011), did not occur in this experiment, as observed by Rolando and Litttle (2008) in seedlings of E. grandis, and by Correia et al. (2014) in E. globules subjected to water stress. Like those authors, it is possible to conclude that the $\mathrm{Fv} / \mathrm{Fm}$ ratio does not reflect the water status of the plants, differing from results found by Lima, Rhizopoulou and Jarvis (2003). When a plant has its photosynthetic apparatus intact, the $\mathrm{Fv} / \mathrm{Fm}$ ratio is close to 0.82 , while a fall in this ratio reflects the presence of photoinhibition damage to the reaction centres of photosystem II (BJORKMAN; DEMMING, 1987). It follows that the water stress imposed by the regimes did not cause damage to photosystem II, despite the difference seen between $\mathrm{H} 3$ and H5.

The highest values for the chlorophyll content index (CCI), seen in plants subjected to the less frequent irrigation regimes regardless of hybrid, corroborate the results obtained by Correia et al. (2014) in E. globules, and by Vellini et al. (2008) in 18 hybrid clones of the Eucalyptus. These last authors also found that the highest values for CCI, besides being seen in treatments with a lower irrigation frequency, were associated with smaller plant growth, which may have resulted in greater concentration of $\mathrm{N}$ in the leaves. Although a reduction in chlorophyll content was reported in plants under stress attributed to degradation (FANAEI et al., 2009), the higher level in plants cultivated under low water availability may be a defence mechanism in which the concentration of chlorophyll would help to maintain photosynthesis even with the stomata closed (MICHELOZZI; JOHNSON; WARRAG, 1995). Correia et al. (2014), working with E. globulus, also found a higher chlorophyll content in stressed plants, linking this result to a reduction in leaf expansion and mass. For these authors, the higher chlorophyll content in stressed plants may be related to the supposed 
protective function of carotenoids on the molecular function of chlorophyll, protecting it from degradation and thus preserving photosynthetic capacity.

\section{CONCLUSIONS}

1. Hybrid $\mathrm{H} 3$ is the most tolerant and $\mathrm{H} 5$ the most sensitive to a reduction in water availability in the soil;

2. Changes in stomatal conductance may be used as signs of water stress in the Eucalyptus.

\section{REFERENCES}

ANDRIOLI, I.; CENTURION, J. F. Levantamento detalhado dos solos da Faculdade de Ciências Agrárias e Veterinárias de Jaboticabal. In: CONGRESSO BRASILEIRO DE CIÊNCIA DO SOLO, 27., 1999, Brasília, DF. Anais... Brasília, DF: Sociedade Brasileira de Ciência do Solo, 1999. 1 CD-ROM.

ANGELOCCI, L. R. et al. Transpiration, leaf diffusive conductance, and atmospheric water demand relationship in an irrigated acid lime orchard. Brazilian Journal Plant Physiology, v. 16, n. 1, p. 53-67, 2004.

BEDON, F. et al. Interaction between environmental factors affects the accumulation of root proteins in hydroponically grown Eucalyptus globulus (Labill.). Plant Physiology and Biochemistry, v. 49, n. 1, p. 69-76, 2011.

BJÖRKMAN, O.; DEMMING, B. Photon yield of $\mathrm{O}_{2}$ evolution and chlorophyll fluorescence characteristics at $77 \mathrm{k}$ among vascular plants of diverse origins. Planta, v. 170, n. 4, p. 489-504, 1987.

BLACKMAN, C. J.; BRODRIBB, T. J.; JORDAN, G. J. Leaf hydraulics and drought stress: response, recovery and survivorship in four woody temperate plants species. Plant, Cell and Environment, v. 32, n. 11, p. 1584-1585, 2009.

CHAVES, M. M.; FLEXAS, J.; PINHEIRO, C. Photosynthesis under drought and salt stress: regulation mechanisms from whole plant to cell. Annals of Botany, v. 103, n. 4, p. 551-560, 2009.

CHAVES, M. M.; MAROCO, J.P.; PEREIRA, J. S. Understanding plant responses to drought - from genes to the whole plant. Functional Plant Biology, v. 30, n. 3, p. 239-264, 2003.

CHAVES, M. M. et al. Non-stomatal limitation of photosynthesis under high temperature and water deficits in Lupinus albus. Photosynthetica, v. 27, p. 521-528, 1992.

CORREIA, B. et al. Water stress and recovery in the performance of two Eucalyptus globulus clones: physiological and biochemical profiles. Physiologia Plantarum, v. 150, n. 4, p. 580-592, 2014.

EKSTEEN, A. B. et al. Stomatal characteristics of Eucalyptus grandis clonal hybrids in response to water stress. Southern Forests: a Journal of Forest Science, v. 75, n. 3, p. 105-111, 2013.

FANAEI, H. R. et al. Amelioration of water stress by potassium fertilizer in two oilseed species. International Journal of Plant Production, v. 3, n. 2, p. 41-54, 2009.
FRETZ, T. A.; READ, P. E.; PEELE, M. C. Plant propagation Lab manual. Mineapolis, USA: Burgess Publishiny Company, 1979. 317 p.

GONÇALVES, J. L. M.; VAN RAIJ, B.; GONÇALVES, J. Q. Florestas. In: VAN RAIJ, B. et al. (Ed.) Recomendações de adubação e calagem para o estado de São Paulo. 2. ed. Campinas: Instituto Agronômico/Fundação IAC, 1997. p. 247-259. (Boletim Técnico, 100).

HU.; CHEN, H; HU, T. Adaptability comparison between the seedlings of Eucalyptus grandis and Almus cremastogyne under the condition of continuous drought stress. Journal of Agricultural Science, v. 4, n. 4, p. 75-86, 2012.

LAWLOR, D. W. Musings about the effects of environment on photosynthesis. Annals of Botany, v. 103, n. 4, p. 543-5549, 2009.

LAWLOR, D. W.; TEZARA, W. Causes of decreased photosynthetic rate and metabolic capacity Causes of decreased photosynthetic rate and metabolic capacity in water-deficient leaf cells: a critical evaluation of mechanisms and integration of processes. Annals of Botany, v. 103, n. 4, p. 561-579, 2009.

LIMA, W. P.; JARVIS, P.; RHIZOPOULOU, S. Stomatal responses of Eucalyptus species to elevated $\mathrm{CO}_{2}$ concentration and drought stress. Scientia Agrícola, v. 60, n. 2, p. 231-238, 2003.

MICHELOZZI, M.; JOHNSON, J.; WARRAG, E. Response of ethylene and chlorophyll in two Eucalyptus clones during drought. New Forest. v. 9, n. 1, p. 197-204, 1995.

MOKOTEDI, M. E. O. Physiological responses of Eucalyptus nitens $\times$ nitens under experimentally imposed water stress. Southern Forests, v. 72, n. 2, p. 63-68, 2010.

MOSETI, B.; DINTWE, K. Effect of water stress on photosynthetic characteristics of two sorghum cultivars. The African Journal of Plant Science and Biotechnology, v. 5, p. 89-91, 2011. Special Issue.

NGUGI, M. R. et al. Physiological responses to water stress in Eucalyptus cloeziana and E. argophloia seedlings. Trees, v. 18 , n. 4 , p. 381-389, 2004.

PAUlA, R. C.; PAULA, N. F.; MARINO, C. L. Breeding Perennial Species for Abiotic Stress. In: FRITSCHE-NETO, R.; BORÉM, A. Plant Breeding for Abiotic Stress Tolerance. Springer, 2012, p. 157-172.

PEPPER, D. A. et al. Mechanisms linking plant productivity and water status for a temperate Eucalyptus forest flux site: analysis over wet and dry years with a simple model. Functional Plant Biology, v. 35, n. 6, p. 493-508, 2008.

PINHEIRO, C.; CHAVES, M. M. Photosynthesis and drought: can we make metabolic connections from available data? Journal of Experimental Botany, v. 62, n. 3, p. 869-882, 2011.

PITA, P. et al. Use of physiological traits in tree breeding for improved yield in drought-prone environments. The case of Eucalyptus globulus. Investigación Agraria: Sistemas y Recursos Forestales, v. 14, n. 3, p. 383-393, 2005.

ROLANDO, C. A.; LITTLE, K. M. Measuring water stress in Eucalyptus grandis Hill ex Maiden seedlings planted into 
pots. South African Journal of Botany, v. 74, n. 1, p. 13138, 2008.

SCHOLANDER, P. F. et al. Sap pressure in vascular plants. Science, v. 148, n. 3668, p. 339-346, 1965.

SMIT, M. A.; SINGELS, S. The response of sugarcane canopy development to water stress. Field Crops Research, v. 98, n. $2 / 3$, p. $91-97,2006$.

SOUZA, M. J. H. et al. Disponibilidade hídrica do solo e produtividade do eucalipto em três regiões da Bacia do Rio Doce. Revista Árvore, v. 30, n. 3, p. 399-410, 2006.

STAPE, J. L. et al. The Brazil Eucalyptus Potential Productivity Project: Influence of water, nutrients and stand uniformity on wood production. Forest Ecology and Management, v. 259, n. 9, p. 1684-1694, 2010.

VELLINI, A. L. T. T. et al. Respostas fisiológicas de diferentes clones de eucaliptos sob diferentes regimes de irrigação. Revista Árvore, v. 32, n. 4, p. 651-663, 2008.

VILLAR, E. et al. RNA-Seq reveals genotype-specific molecular responses to water deficit in eucalyptus. BMC Genomics, v. 12, n. 538, p. 1-18, 2011.

WARREN, R. C.; ARANDA, I.; CANO, J. F. Responses to water stress of gas exchange and metabolites in Eucalyptus and Acacia spp.Plant, Cell and Environment, v. 34, n. 10, p. 1609-1629, 2011. 